Volume 8

Issue 3 Humanitarian Technologies and

Genocide Prevention

Article 8

October 2014

\title{
Documenting Mass Rape: Medical Evidence Collection Techniques as Humanitarian Technology
}

Jaimie Morse

Northwestern University

Follow this and additional works at: https://digitalcommons.usf.edu/gsp

\section{Recommended Citation}

Morse, Jaimie (2014) "Documenting Mass Rape: Medical Evidence Collection Techniques as

Humanitarian Technology," Genocide Studies and Prevention: An International Journal: Vol. 8: Iss. 3:

63-79.

DOI:

http://dx.doi.org/10.5038/1911-9933.8.3.6

Available at: https://digitalcommons.usf.edu/gsp/vol8/iss3/8

This Articles is brought to you for free and open access by the Open Access Journals at Digital Commons @ University of South Florida. It has been accepted for inclusion in Genocide Studies and Prevention: An International Journal by an authorized editor of Digital Commons @ University of South Florida. For more information, please contact digitalcommons@usf.edu. 


\section{Documenting Mass Rape: Medical Evidence Collection Techniques as Humanitarian Technology}

\section{Acknowledgements}

I would like to thank all those who generously agreed to be interviewed for this project. Steven Epstein, Carol A. Heimer, John Hagan, Ken Alder, Wendy Griswold, Terence Halliday, Helen Tilley, Amy J. Ross, Chandra Lekha Sriram, my 2013 SSRC DPDF cohort, and two anonymous reviewers provided invaluable feedback and suggestions. My colleagues at Northwestern University and the American Bar Foundation fostered ideas and pushed my thinking, especially Jessica Koski, Gemma Mangione, Diana Rodriguez Franco, Savina Balasubramanian, Nisa Goksel, Alka Menon, Jamie Rowen, Christopher Carroll, Talia Shiff, David Peterson, Daphne Demetry, Dawna Goens, Maureen Warren, and the participants in the Science in Human Culture Doctoral Colloquium, the Culture and Society Workshop, and the Legal Studies Program. Any errors or omissions are mine alone. This research was assisted by a fellowship from the Dissertation Proposal Development Fellowship Program of the Social Science Research Council with funds provided by the Andrew W. Mellon Foundation; the Science in Human Culture program at Northwestern University; the Presidential Fellowship at Northwestern University; the Partnership University Fund (through Northwestern University and Sciences Po); and the Center on Law and Globalization, a joint project of the American Bar Foundation and the University of Illinois College of Law. 


\title{
Documenting Mass Rape: Medical Evidence Collection Techniques as Humanitarian Technology
}

\author{
Jaimie Morse* \\ Department of Sociology \\ Northwestern University \\ Evanston, IL, USA
}

\begin{abstract}
:
Aim: Emerging global networks of human rights activists, doctors, and nurses have advocated for increased collection of medical evidence in conflict-affected countries to corroborate allegations of sexual violence and facilitate prosecution in international and domestic courts. Such initiatives are part of broader shifts in human rights advocacy to document human rights violations using rigorous, standardized methodologies. In this paper, I consider three principal forms of medical evidence to document sexual violence and their use in these settings: the patient medical record, the medical certificate, and the sexual assault medical forensic exam (commonly known as the "rape kit").

Methods: Combining archival research with interviews of activists, healthcare practitioners, lawyers, investigators, and other experts, I trace the collection and use of medical evidence to document mass rape since the establishment of the International Criminal Tribunals for Rwanda and the former Yugoslavia.

Results: The use of medical evidence collection techniques to document sexual violence during and shortly after armed conflict or mass violence against civilians is still relatively new and not well institutionalized. When available, medical evidence has been used to document patient disclosures, describe patterns of crime, prompt investigation, issue indictments, and provide context evidence to establish international crimes occurred.

Conclusions: Drawing on approaches in science and technology studies, law and society, and cultural sociology, I argue that medical evidence collection techniques represent an emerging humanitarian technology that may influence what comes to count as sexual violence, which crimes are deemed justiciable, and ultimately how events come to be remembered, within and beyond courts.
\end{abstract}

Keywords: medical evidence; rape kits; sexual assault medical forensic exam; medical certificate; mass rape; sexual violence in conflict

\section{Introduction}

Calls to address sexual and gender-based violence in conflict have garnered international attention, marked most recently by the largest global event ever held on the subject in June 2014: the United Kingdom's Global Summit to End Sexual Violence in Conflict, co-hosted by British Foreign Secretary William Hague and United Nations High Commissioner for Refugees Special Envoy Angelina Jolie. At the Global Summit, the United Kingdom's Foreign and Commonwealth Office (UK FCO) published and disseminated the UK's new International Protocol ${ }^{1}$ (hereafter, UK protocol), which is intended to guide first responders in collecting and preserving evidence of sexual violence during or shortly after armed conflict, even if prosecution is unlikely to occur until much later. Although medico-legal interventions are not the focus, the protocol names specially trained doctors and nurses as among the first responders who may collect victim testimony, create and maintain documentation of disclosures by patients, and, where possible, collect and preserve physical evidence.

A principal focus of the UK's Global Summit and the launch of the UK protocol was to increase investigation and prosecution of sexual violence in armed conflict. ${ }^{2}$ Although landmark cases at the

\footnotetext{
*I would like to thank all those who generously agreed to be interviewed for this project. Steven Epstein, Carol A. Heimer, John Hagan, Ken Alder, Wendy Griswold, Terence Halliday, Helen Tilley, Amy J. Ross, Chandra Lekha Sriram, my 2013 SSRC DPDF cohort, and two anonymous reviewers provided invaluable feedback and suggestions. My colleagues at Northwestern University and the American Bar Foundation fostered ideas and pushed my thinking, especially Jessica Koski, Gemma Mangione, Diana Rodriguez Franco, Savina Balasubramanian, Nisa Goksel, Alka Menon, Jamie Rowen, Christopher Carroll, Talia Shiff, David Peterson, Daphne Demetry, Dawna Goens, Maureen Warren, and the participants in the Science in Human Culture Doctoral Colloquium, the Culture and Society Workshop, and the Legal Studies Program. Any errors or omissions are mine alone.
}

This research was assisted by a fellowship from the Dissertation Proposal Development Fellowship Program of the Social Science Research Council with funds provided by the Andrew W. Mellon Foundation; the Science in Human Culture program at Northwestern University; the Presidential Fellowship at Northwestern University; the Partnership University Fund (through Northwestern University and Sciences Po); and the Center on Law and Globalization, a joint project of the American Bar Foundation and the University of Illinois College of Law. 
International Criminal Tribunal for Rwanda (ICTR) and the International Criminal Tribunal for the Former Yugoslavia (ICTY) have successfully established rape as a war crime, a crime against humanity, and, in the Akayesu case, ${ }^{3}$ an instrument of genocide, few subsequent cases referred to the International Criminal Court (ICC) have led to arrest or prosecution. Despite continued advocacy and ongoing ICC investigations ${ }^{4}$ into allegations of mass atrocities ${ }^{5}$ in several countries, barriers to prosecution persist in both domestic and international courts.

Intended to address these barriers to prosecution, a growing number of interventions in conflict and post-conflict areas involve training healthcare practitioners in medical evidence collection techniques to corroborate allegations of rape and other forms of sexual ${ }^{6}$ violence. Such initiatives often seek to combine specialized medical care and treatment for survivors of sexual violence with increased medical documentation of patient narratives, physical injuries, and psychological sequelae in order to facilitate prosecution in domestic and international courts. However, new procedures, rules, and norms often accompany new techniques and may conflict with existing norms, practices, and political interests in the environments in which they are introduced. As a result, processes of transnational diffusion and circulation of new techniques inevitably involve resistance, adaptation, and innovation by domestic actors who often must do substantial work to make new laws, rules, norms, and technologies - often formulated in the Global North - relevant in new contexts and environments - often in the Global South - to which they are not always well-suited. ${ }^{7}$

Attempts to standardize, professionalize, and more routinely implement medical evidence collection techniques and adapt them to a somewhat new purpose are part of broader shifts in the field of human rights advocacy to document and measure human rights violations using rigorous and standardized methodologies. Activist-professionals have marshaled their disciplinary tools and expertise to produce evidence of mass atrocities through a variety of technologies, including the use of sophisticated sampling and survey techniques to produce population-based estimates of mortality, morbidity, and more recently sexual violence in war; application of death investigation techniques and forensic science to exhume mass graves and identify human remains; and acquisition of commercial satellite images to capture population displacement and destruction of physical structures. Similarly, medical evidence collection techniques are designed to measure and record characteristics of sexual violence and its effects on patient-victims that may serve as a tool to advance human rights advocacy, prompt investigation, and bear witness to atrocities.

Yet evidence collection techniques may in fact help to define what they purport to measure, thereby having profound symbolic and material effects on the perceived credibility of victims' narratives of events and ultimately which narratives are included in formally recorded histories of mass atrocities. In the case of human rights advocacy, documentation of rights violations often is explicitly intended to have such definitional effects in order to name and thereby symbolically sanction crime. Such evidence may also suggest that specific violations of international humanitarian law have occurred and establish the jurisdiction of specialized international and hybrid courts to investigate Heads of State and other high level officials who may be responsible. For example, estimated counts of numbers of persons killed, displaced, or raped have been at the center of debates about whether or not genocide occurred in the Balkans ${ }^{8}$ and Darfur9.

The use of medical evidence collection techniques with surviving patients ${ }^{10}$ during and shortly after armed conflict and episodes of mass violence against civilians is still relatively new and not well institutionalized, even in settings in which specialized physician training and capacity to collect and analyze forensic evidence ${ }^{11}$ exist. Therefore, in this paper, I consider three forms of medical documentation and their associated evidence collection techniques and provide examples of their use in documenting sexual violence in contexts of armed conflict, humanitarian emergencies, and mass violence against civilians: the patient medical record, the medical certificate, and the sexual assault medical forensic exam and its associated forensic evidence collection kit (often referred to as the "rape kit"). ${ }^{12}$

Drawing on approaches in science and technology studies, law and society, and cultural sociology, I argue that, like other technologies, medical evidence collection techniques designed to corroborate rape ${ }^{13}$ reflect their historical origins in place and time, and their character, use, and potential effects are likely to vary in new contexts of armed conflict and mass violence. Historically such techniques were developed to document individual harms to individual victims by direct perpetrators and collect corroborative evidence for use in domestic courts. Their adaptations for use in contexts of armed conflict and mass violence signal the differences in scale between individual and collective crimes of sexual violence and the barriers to prosecution of sexual violence as an international crime in the national jurisdictions in which it has occurred, with potentially far-reaching effects within and beyond courts. 
This paper is divided into six sections. First, I describe the data and methods on which I draw. Next, I provide an overview of the historical origins of medical evidence as a means of corroborating allegations of rape in domestic courts and the differences in scale that arise when attempting to prosecute sexual violence as a violation of international humanitarian law. To illustrate these differences, I describe the legal definitions of crime, more flexible evidentiary standards, and innovative rules of procedure and evidence developed by the ICTY and ICTR to facilitate prosecution of sexual violence as a war crime, crime against humanity, and instrument of genocide and demonstrate how they differ from national jurisdictions. In sections three, four, and five, I discuss three types of medical evidence and provide examples of their recent use in contexts of armed conflict, humanitarian emergencies, and mass violence against civilians as a means of documenting and adjudicating individual and collective crimes of sexual violence in such environments: re-purposing routinely collected patient medical records as evidence in investigation and prosecution of international crimes of sexual violence; issuing medical certificates as part of basic medical care in humanitarian emergencies; and offering sexual assault medical forensic exams during and immediately following episodes of mass violence against civilians for use in the national jurisdictions in which the crimes occurred. Finally, given the relatively recent introduction of these techniques in settings of armed conflict and mass violence and the limited research available to date, I offer questions for consideration and propose areas for future research. I suggest that medical evidence collection techniques may influence what comes to count as sexual and gender-based violence in armed conflict, which crimes are deemed justiciable, and ultimately how events come to be remembered. In this way, medical evidence collection techniques represent an emerging humanitarian technology that may contribute to formally recorded histories of mass atrocities while simultaneously reflecting and influencing understandings of sexual violence in war and representations of survivor experiences.

\section{Methods}

My approach combines archival research with interviews of activists, healthcare practitioners, lawyers, investigators, and other experts who have sought to use their professions, expertise, and evidence collection techniques in service of human rights advocacy-individuals who have been instrumental in generating medical evidence to document sexual violence as a central component of women's rights and human rights advocacy since the 1970s, with particular emphasis on the evolution of such techniques to address sexual and gender-based violence in war as a focus of international advocacy since the $1990 \mathrm{~s}^{14}{ }^{14}$ In this paper, I consider uses of medical evidence broadly defined, including routinely collected treatment records, medical certificates, sexual assault medical forensic exams (commonly known as "rape kits"), adaptations of medical forensic exams developed for use with survivors of torture, and statistics generated from aggregated, de-identified data based on such records. I describe how medical evidence, when available, has been used to characterize patterns of crime, provide context evidence, facilitate the issuance of indictments, and support case prosecution before specialized international and hybrid courts since the establishment of the ICTY and ICTR. I draw on publicly available reports, court documents from cases brought before specialized international and hybrid courts, and published research articles to reconstruct this recent history and inform my understanding of contemporary uses of medical evidence collection techniques for these purposes.

\section{Differences in Scale and Context: Historical Origins of Medical Evidence to Document Rape in Domestic Courts and its Contemporary Uses in Settings of Armed Conflict, Humanitarian Emergencies, and Mass Violence Against Civilians}

Medical evidence has long been used to adjudicate crime, and doctors have served as expert witnesses in court for this purpose since at least the $19^{\text {th }}$ century. However, attempts to standardize and professionalize medical evidence collection techniques in order to improve available evidence and facilitate legal advocacy on behalf of surviving patient-victims appear to be relatively recent, beginning in the 1970s and continuing to the present. For example, beginning in the 1970s, practitioner-activists allied with the reform agenda of the anti-rape wing of the second wave feminist movement in the United States sought to reform law enforcement and healthcare approaches to sexual violence. They attempted to create more victim-centered models of care, in part by advocating for routine collection of medical forensic evidence by specially trained healthcare personnel in order to corroborate allegations of rape. ${ }^{15}$ Similar reforms have been implemented in Western Europe. During the same period, doctors associated with the global anti-torture movement sought to provide specialized medical care and treatment for survivors of torture, document and classify physical injuries and psychological trauma resulting from different methods of torture, and facilitate prosecution; these efforts 
ultimately led to the adoption of the Istanbul Protoco ${ }^{16}$ designed to guide physicians in conducting medical forensic exams with survivors of torture.

Initially, these techniques and guidelines were developed for use in domestic jurisdictions. Since the 1990s, increased medical documentation of physical injury and collection of forensic evidence (when possible) have been codified as a component of specialized medical care and treatment for survivors of sexual violence in medico-legal guidelines adopted by the World Health Organization (WHO) in 2003. ${ }^{17}$ These guidelines outline best practices in medical care for surviving victims of sexual violence. In 2004, these guidelines were adapted for use with refugees and internally displaced persons. ${ }^{18}$

In contrast, in the 1970s, the relatively young professional field of what has come to be known as "transitional justice" and its associated Truth Commissions and specialized international and hybrid courts established to prosecute war crimes, crimes against humanity, and genocide post-Nuremberg had yet to emerge. Historically, medical evidence of sexual violence during armed conflict was not available or required as corroborative evidence in specialized international and hybrid courts. However, in the last 10-15 years, an increasing number of organizations have introduced or adapted medical evidence collection techniques for use in settings of ongoing or recent armed conflict, mass violence, and humanitarian emergencies. While feminist scholars of transitional justice have long identified barriers to seeking justice in court for survivors of sexual violence, few studies to date have examined the origins and effects of medical evidence collection techniques introduced to document mass rape and meet the evidentiary requirements of international and domestic courts.

To contextualize these developments within the recent history of transitional justice and international criminal law post-Nuremberg, I provide a brief overview of the legal definitions of rape and other forms of sexual and gender-based violence developed by the ICTY and ICTR, their innovative rules of procedure and evidence, and the tensions that arise when international crimes of sexual violence are prosecuted by domestic courts in the national jurisdictions in which the crimes occurred.

\section{Prosecuting International Crimes of Sexual Violence Before the International Criminal Tribunals for Rwanda and the Former Yugoslavia}

In 1993, the ICTY was established to prosecute mass atrocities in the Balkans, the first such international court since Nuremburg. As John Hagan has chronicled in his ethnography of the early years of the ICTY, prosecutors were initially reluctant to investigate and prosecute sexual violence cases. ${ }^{19}$ Internal advocacy by predominately female prosecutors and investigators pushing for investigation against the backdrop of public outrage at reports of mass rape within Bosnia was instrumental in prompting the court to bring the first rape cases before an international court. Part of this advocacy included the establishment of protective measures for victims of sexual violence that signaled the divergence of the court from legal requirements of corroboration and proving lack of consent typically required in national jurisdictions. These innovations in rules of procedure and evidence have become understood as among the landmark achievements heralded by the ICTY ${ }^{20}$ and were later adopted and codified as part of the founding Rome Statute ${ }^{21}$ of the ICC. ${ }^{22}$

Evidentiary requirements are closely tied to available definitions of crime, modes of liability, and procedural protections for victims in domestic and international courts. The crime of rape illustrates key differences between international and domestic courts and their implications for survivors' access to justice.

\section{Defining the act of rape}

Definitions of rape as a crime under international humanitarian law were first developed within the jurisprudence of the ICTR and ICTY. ${ }^{23}$ A landmark decision by the ICTR, the Akayesu case, established that rape could be legally and criminally sanctioned as an instrument of genocide and a crime against humanity. The decision defined rape broadly as "a physical invasion of a sexual nature, committed on a person under circumstances which are coercive"; ${ }^{24}$ the court also recognized forced nudity as a form of sexual violence constituting inhumane acts as crimes against humanity. ${ }^{25}$ In the subsequent Furundžija case, the ICTY provided an explicit judicial definition of rape in terms of human vaginal, anal, or oral penetration with genitalia or with objects through coercion or the use or threat of force. ${ }^{26}$

Subsequently, the ICC Elements of Crimes defined rape (as a crime against humanity) as the invasion of the body of the victim by the perpetrator (including oral, anal, or vaginal penetration with genitalia or objects) through the use or threat of force, coercion, or by taking advantage of a coercive environment. Both men and women can be victims. ${ }^{27}$ Domestic criminal penal codes may or may not criminalize all forms of sexual violence recognized by the international courts. 


\section{Establishing the context in which rape occurred}

In addition to demonstrating that an act of rape occurred (however defined), prosecutors must also establish that the specific elements of the relevant category of international crime have also been met. In the case of war crimes, crimes against humanity, and genocide, this explicitly involves an environment of coercion, such as armed conflict or mass violence. For example, the definition of crimes against humanity in Article 7 of the Rome Statute ${ }^{28}$ stipulates that any of the enumerated acts $^{29}$ must have been committed as part of a "widespread or systematic attack" directed against civilians.

\section{Determining modes of liability}

International courts also attempt to prosecute those most responsible at the highest levels in the chain of command. Sometimes high level perpetrators can be tied directly to the crime; more often prosecutors must link lower level, direct perpetrators not only to victims, but also to remote perpetrators with command or superior responsibility. This has been a particular challenge in cases of sexual violence. In domestic jurisdictions, similar challenges may arise. Innovative legal strategies to hold high level perpetrators accountable under rubrics such as "joint criminal enterprise" and command responsibility may not be available, and liability modes based on conspiracy differ from jurisdiction to jurisdiction. They may not be available to prosecutors in local jurisdictions.

\section{Innovative Rules of Procedure and Evidence}

Reflecting these differences in scale and context, the ICTR and ICTY Rules of Procedure and Evidence (RPE) established protective measures for victims of sexual violence that differ from many national jurisdictions. Rule 96 of both the ICTR RPE ${ }^{30}$ and ICTY RPE ${ }^{31}$ established the following protections for victims of sexual violence:

1) Corroboration of victim testimony is not required;

2) Information about the victim's prior sexual conduct cannot be admitted as evidence;

3) Lack of consent can be inferred from the environment of coercion that characterizes war, mass violence, and detention. ${ }^{32}$

The ICC RPE codified similar protections in Rules 70, 71, and $72 .{ }^{33}$ Additionally, according to Rule 63 of the ICC RPE, corroboration is not required to prove any crime within the jurisdiction of the ICC. In international courts, victim testimony alone is sufficient to prosecute and convict. In practice, corroborating evidence strengthens cases. However, such corroboration need not be physical evidence, such as medical or forensic evidence; witness testimony and other forms of documentary evidence can serve this purpose as well. For example, all of the landmark rape cases at the ICTY ${ }^{34}$ relied on victim and witness testimony to establish criminal responsibility for rape. $35,36,37,38,39$ Similarly, the landmark rape cases at the ICTR ${ }^{40}$ also relied on victim and witness testimony. ${ }^{41,42}$

\section{The element of non-consent: rape as a war crime, crime against humanity, and genocide}

In this context, the question of whether or not lack of consent should be an element of the crime when rape and other forms of sexual and gender-based violence are committed as part of armed conflict and mass violence has been a point of debate in the field. ${ }^{43}$ Many scholars and practitioners have argued that lack of consent can be inferred from the environment of coercion that characterizes detention, armed conflict, and mass atrocities. ${ }^{44}$ Parallels have been made to domestic laws prohibiting torture and criminalizing rape of inmates by prison guards in which lack of consent is assumed. ${ }^{45}$

Even if lack of consent is an element of the crime under international law, prosecutors must provide evidence that a coercive environment exists, rather than prove lack of consent by the victim to the particular act in question. These alternative grounds to establish lack of consent may not be available under domestic penal codes, although laws prohibiting torture may be.

\section{Prosecuting International Crimes of Sexual Violence in National Jurisdictions}

The founding Rome Statute of the ICC established the ICC as a court of last resort to which plaintiffs only have recourse if local courts are unable or unwilling to prosecute those responsible. This principle of complementarity positions national courts as the first place that victims must seek justice. However, even 
when existing national laws or treaty obligations may be understood to enable prosecution of international crimes in local courts, available definitions of crime, modes of liability, and rules of procedure and evidence may differ from those established by the ICC and other specialized international and hybrid courts For example, unlike international specialized and hybrid courts, corroborating evidence is often required in national jurisdictions, and medical or forensic evidence may be a formal or informal requirement in order for a case to go forward in court.

In response to these requirements, efforts to facilitate prosecution of war crimes and crimes against humanity within the national jurisdictions in which they have occurred have led to an increasing number of initiatives to introduce, standardize, and professionalize medical evidence collection in order to increase the availability of medical evidence whenever possible. In the next three sections, I discuss three types of medical evidence that have been collected in settings of armed conflict, humanitarian emergencies, and mass violence against civilians: the patient medical record, the medical certificate, and the sexual assault medical forensic exam. .

\section{Re-Purposing Routinely Collected Patient Medical Records as Evidence for Investigation and Prosecution of International Crimes of Sexual Violence}

Individual patient records held by hospitals, clinics, or non-governmental organizations can be used to corroborate victim testimony and to generate statistics based on aggregated, de-identified patient data that may facilitate investigation, indictment, and prosecution. The patient medical record documents the medical encounter: why a patient seeks healthcare, what symptoms or injuries the patient reports, and what diagnoses, treatment, or recommendations a healthcare provider makes. In this way, patient records can be used as a source of data for statistics generated from complex or rudimentary medical chart extraction. Such statistics may describe patterns of patient reporting, injuries, pregnancies, related medical procedures (such as abortion where it is legal), and other reported and observed health sequelae.

In addition, routinely collected medical records can provide corroborating evidence even when they were not initially collected for the purposes of criminal investigation and prosecution. Hospitals and clinics in a specific geographic area may be among the first places that surviving victims go after a specific event (such as a massacre), during ongoing war, or after they have arrived at refugee camps receiving those displaced and fleeing armed conflict. Of course, healthcare systems may be severely under-resourced, poorly functioning, or completely demolished during and immediately following armed conflict. For this reason, specialized healthcare services may not be available to a majority of victims of conflict-related sexual violence. Nevertheless, where medical care exists, however rudimentary it may be, there have been attempts to increase the capacity of existing healthcare personnel to treat and sometimes also medically document rape.

To describe such re-purposing of existing medical records for the purposes of investigation and prosecution, I discuss three examples of such uses of the patient medical record: (i) establishing that mass rape had occurred in the former Yugoslavia in 1992 based on medical records, (ii) introducing evidence of post-traumatic stress disorder in the Furundžija case at the ICTY, and (iii) providing context evidence in the Taylor case at the Special Court for Sierra Leone (SCSL).

\section{Estimating Mass Rape Using Hospital Records in the Former Yugoslavia}

The war in the former Yugoslavia began in 1992, and media reports suggested that large numbers of women had been raped as part of the armed conflict. In January 1993, an investigative team including four doctors visited hospitals and medical centers in Croatia, Bosnia, and Serbia. They were able to document the number of women seeking medical care according to physician reports and existing medical records at six hospitals in Zagreb, Sarajevo, Zenica, and Belgrade. The findings of the expert team are included as Annex II in the report submitted to the UN Commission on Human Rights in February 1993 by Tadeusz Mazowiecki, Special Rapporteur of the Commission. ${ }^{46}$ Based in part on their findings, the Special Rapporteur concluded that rape was widespread, but noted that the specific number of victims of rape could not be estimated based on available data.

In Annex II to the Special Rapporteur's report, the expert team reported that 119 pregnancies related to rape had been documented, either disclosed directly to physicians by victims seeking healthcare or as part of procedures to secure access to second trimester abortions. Based on the assumption that only one out of 100 incidents of rape result in pregnancy, they estimated that these pregnancies represented approximately 12,000

incidents of rape, with the caveat that many of these women reported being raped more than once. The team also documented rates of birth, abortion, and sexually transmitted diseases, in addition to pregnancies. They 
compared the ratio of deliveries to abortions in 1992 with the ratio in the preceding year (1991) to determine if elevated rates of abortion could be observed. They found stable rates in Zagreb and Belgrade, but found some evidence of elevated abortion rates in Sarajevo and Zenica in 1992.

Five months later, in August 1993, one of the members of the investigative team co-authored an article entitled "Rape as a Crime of War: A Medical Perspective" in The Journal of the American Medical Association (JAMA). ${ }^{47}$ The JAMA article summarized the methodology of the investigative team and reported the same number of pregnancies resulting from rape that were published as Annex II to the Special Rapporteur's report. The authors noted that this number probably represented only a fraction of all pregnancies resulting from rape due to widespread reluctance of victims to disclose. They also estimated that these 119 pregnancies recorded at a small sample of only six hospitals in Bosnia, Croatia, and Serbia represented 11,900 incidents of rape, based on existing medical data suggesting that a single act of unprotected intercourse results in pregnancy about $1 \%$ - $4 \%$ of the time. They further suggested that "techniques of medical science" could help "validate testimony of individual rape" with procedures used in criminal cases in the United States, including collection of sperm if the victim reports within 24-48 hours of the incident and preserving the placenta after an abortion for later DNA identification.

Although these figures do not appear to have been cited in ICTY court records or indictments, they suggested that rape was widespread and laid the foundation for using similar techniques in other conflicts. By comparing "baseline" (i.e., peacetime) and wartime pregnancy/abortion rates, observed spikes in pregnancy and abortion rates could document elevated, and therefore possibly war-related, pregnancies and abortions, which in turn could suggest that widespread rape during war had occurred. The authors of such statistics recognize that associations between elevated pregnancy and abortion rates and periods of armed conflict are only suggestive and could be the result of causes other than war-related rape. Nevertheless, such documentation techniques were used to suggest that rape was widespread and prompt further investigation.

These efforts to use patient records and service utilization data to estimate numbers of persons raped during the conflict resemble similar uses of population-based demographic and health surveys for this purpose. In countries where demographic and health survey data was collected prior to armed conflict, existing data can be used to establish "baseline" prevalence rates of rape and sexual violence. These estimates can then be compared to the results of subsequent surveys and used to estimate elevated rates during armed conflict. More recently, researchers have sought to combine health surveys with crime victimization surveys developed in the field of criminology to also ask about perpetrators. ${ }^{48,49,50,51}$

\section{Introducing Evidence of Post-Traumatic Stress Disorder in The Furundžija Case at the ICTY}

Although the landmark rape cases at the ICTY did not involve physical evidence (including medical evidence) as corroboration of victim testimony in compliance with innovative rules of procedure and evidence at the ICTY described above, one landmark ICTY rape case, Furundžija et al. ${ }^{52}$ involved the introduction of a psychological assessment and diagnosis of PTSD as evidence of psychological trauma experienced by the victim as a result of rape. What unfolded in court suggests the potential liabilities of introducing medical and psychiatric evidence that may be used against the victim in the context of adversarial court proceedings.

In the Furundžija case, the prosecution failed to disclose until the end of the trial that the victim had received services at the Medica Women's Therapy Center, a nongovernmental organization operating in Zenica, Bosnia. The defense then petitioned for the court to admit what the court called a "medical certificate" from the organization, intending to show that the victim had sought psychological counseling, had been in serious emotional distress due to the trauma of the rape, and exhibited symptoms of PTSD. In this case, the medical certificate was an internal intake form with the victim's name redacted to conceal her identity; it was not a medical certificate issued by a doctor for the purposes of criminal investigation that I will discuss below. The victim denied having received psychological treatment at the organization and said that she had never received a diagnosis of PTSD or treatment for such a diagnosis. Nevertheless, once the evidence was admitted, the defense seized the opportunity to use the certificate as evidence of PTSD in order to bolster its argument that, since PTSD is sometimes associated with unreliable memory, the victim's testimony should not be considered credible.

Although the court eventually ruled that the victim's testimony was both credible and persuasive and subsequently convicted the accused, the victim still had to return to court to respond to questions by the defense about the reliability of her memory, her ability to identify the accused as present during the crimes in question, and her own credibility as a witness to the abuses she herself suffered. For victim advocates following 
this trial, the fact that the defense attempted to use a psychiatric diagnosis against the victim in court was an outrage. This case also speaks to the fact that medical evidence often has an ambivalent, indeterminate character: it can be inconclusive; it requires interpretation; and rarely can it prove that a crime occurred without victim and witness testimony establishing that elements of the crime in question have been met and proven beyond a reasonable doubt.

\section{Using Aggregated Data From Medical Records as Context Evidence in The Taylor Case at the SCSL}

Investigators can derive patterns of crime from aggregated, de-identified medical records and witness testimony provided by doctors about patterns of patient help-seeking. In aggregate, such records and witness testimony can be used to document large numbers of patients seeking medical care within a specific window period following acute moments of political unrest, massacres, or military campaigns in order to prompt investigation, issue indictments, and provide context evidence in court. Context evidence helps to establish that a particular series of events are plausible and occurred in a particular place by particular groups of perpetrators to particular groups of victims.

In the Taylor case $^{53}$ prosecuted under the jurisdiction of the SCSL, aggregated data from patient medical records was introduced as context evidence. In this case, the court's judgment included documentary evidence about the number of women seeking medical care at a nongovernmental organization in Freetown after being abducted by RUF and AFRC, forced into sexual slavery, and sometimes treated as "bush wives" by these armed groups.

This nongovernmental organization, the Sierra Leonean Chapter of the Forum for African Women Educationalists (FAWE), had established a sexual violence counseling and health care program after the January 1999 Freetown invasion and documented serving 1,862 female abductees within its first six months of operation, most of whom were from Freetown. A gynecologist working with the FAWE medical team (Prosecution Witness TF1-081) compiled a report describing the characteristics of patients seeking medical care from the FAWE medical team from March to December 1999. He testified that in this period the medical team treated 1,168 patients; of these, $77 \%$ of patients were women, $58.5 \%$ had been sexually abused or raped, $52 \%$ suffered from sexually transmitted diseases, and $17.1 \%$ had become pregnant. ${ }^{54}$

In this way, medical records helped to demonstrate that rape of civilians was widespread and systematic, thereby serving as context evidence that crimes against humanity had been committed. Given the sheer numbers of victims affected, high-level persons would have to have been aware that it was occurring and therefore could be held responsible for the crimes in question. As this example suggests, even when a formal sexual assault medical forensic exam is not conducted, a doctor may still testify to the fact that a particular group of victims sought medical care for health problems and concerns following rape, and in this case, repeated assaults in the context of sexual slavery.

Unlike specialized international and hybrid courts, often in national jurisdictions a formal medical certificate is required in order for medical documentation of rape to be admissible in local and national courts, even in the context of armed conflict, humanitarian emergencies, and mass violence against civilians. I turn to the issuance of medical certificates below.

\section{Issuing Medical Certificates as Part of Basic Medical Care in Humanitarian Emergencies}

The medical certificate is a formal, medico-legal document used in many national jurisdictions that is completed by a doctor and provides an official record of medical findings following the report of a crime or legal claim that involves medical opinion. In cases of rape and other forms of sexual violence, the requirements for obtaining a medical certificate ${ }^{55}$ vary across national jurisdictions. In some jurisdictions, a victim must first report the crime to police in order to obtain a government-mandated form and then take it to a doctor to be completed. In other jurisdictions, doctors may be able to issue a certificate at the time of the initial visit when the patient first discloses rape to the healthcare provider, or after the initial visit at the victim's request based on the notes in the patient's medical chart. In some countries, only government doctors are allowed to complete medical certificates; private or foreign doctors associated with humanitarian organizations may not have legal standing in domestic courts. Doctors may require that victims pay a fee for completion of the certificate, which can be a significant barrier to victim access. Once issued, a victim can submit the medical certificate to law enforcement personnel (such as police) for the purposes of criminal investigation and prosecution. In some jurisdictions, a completed medical certificate is required in order for a victim to file a case in court. 
The practices surrounding medical certificates vary cross-nationally and depend in part on the evidentiary requirements of domestic laws criminalizing rape, and in part on both formal judicial practices and informal norms stipulating which doctors may participate in criminal investigation and whether or not medical evidence is required for prosecution. However, it is not uncommon for a medical certificate to be required in order for a victim to press charges within national jurisdictions that require corroboration of victim testimony ${ }^{56}$ In these contexts, if a victim cannot seek medical care or cannot afford to pay for a medical certificate (where a fee is required), then the possibility of prosecution may be foreclosed if no other evidence or witness testimony is available.

Such corroboration may be required even if the rape was committed as part of armed conflict or mass violence but is being prosecuted as a violation of national laws. ${ }^{57}$ As discussed above, while some countries have adopted elements of the Rome Statute in their domestic penal codes and effectively enable prosecution of violations of international humanitarian law within domestic jurisdictions, they may or may not have adopted the innovative rules of procedure and evidence developed by the specialized international and hybrid courts. For this reason, without judicial intervention, victims may be questioned about consent or prior sexual conduct, even when rape is committed in the context of political violence or armed conflict.

Of course, the issuance of medical certificates based on medical care received during or after armed conflict depends on the ability and willingness of physicians to provide them. For organizations providing medical care as part of humanitarian aid in emergency settings, participating in criminal investigation may jeopardize their access to populations in need of their assistance, particularly if the perpetrators in question are State or Statelinked actors who may be able to revoke their permission to operate within national borders or may interfere with their operations. The same concerns would be true in areas in which Heads of State are effectively unable to govern, leaving local populations and humanitarian organizations vulnerable to interference by local militias in the surrounding area. In order to be permitted access to areas of unrest and ensure the safety of medical personnel, many emergency medical organizations uphold the principle of medical neutrality, namely that medical professionals must treat any person in need of care regardless of political affiliation and parties to the conflict must not attack or interfere with the delivery of medical care to civilians or soldiers.

For the purposes of exploring medical evidence as a type of humanitarian technology, the issuance of medical certificates highlights the tensions between humanitarian aid and criminal justice mandates that have emerged when rape has been reported, documented, or adjudicated in the context of armed conflict. These tensions may arise whether criminal investigation is being pursued under national or international criminal law. They may occur even when there is no active investigation at the time of medical evaluation, but medical evidence is being collected and stored for future use by the victim.

For many with whom I have spoken, the experience of the emergency medical organization Médecins Sans Frontières/Doctors Without Borders (MSF) in Sudan is emblematic of these tensions. The MSF Foundation/CRASH report authored by Françoise Bouchet-Saulnier and Fabien Dubuet on MSF's experience with investigations and legal proceedings ${ }^{58}$ mentions the temporary imprisonment of the MSF head of mission and field manager in Khartoum in 2005 on suspicion that MSF had given the ICC medical evidence of rape after the ICC announced its decision to indict Sudanese President Omar al-Bashir. Although these two expatriates were released, MSF was ordered to leave the country. Since this incident, some organizations working in similar contexts may have become more conservative in their willingness to issue or handover medical certificates to victims, especially those seeking justice in highly politicized court proceedings or unstable political environments.

MSF's 2009 report Shattered Lives: Immediate Medical Care Vital for Sexual Violence Victims discusses MSF's experiences working with rape victims in several countries. Medical certificates are considered one component of medical care for survivors of sexual violence. ${ }^{59} \mathrm{MSF}$ issues medical certificates at the request of patients and gives them to patients directly; MSF will also store certificates on behalf of victims for later retrieval in case the victim would like to pursue prosecution in the future.

MSF's presence in Congo-Brazzaville in the 1990s led to some of its first efforts to provide specialized medical care for rape victims. ${ }^{60}$ MSF staff were witnessing and hearing reports of mass rape as part of widespread violence and displacement. However, MSF realized once it began issuing medical certificates to patients disclosing rape in Congo-Brazzaville that, even when mass rape is overwhelmingly evident, often there is no visible, physical evidence of injury. The physician must report this fact of no clinical findings on the medical certificate. For this reason, the medical certificate may not assist victims in pursuing prosecution in court.

However, MSF decided to issue medical certificates to all victims, even if there were no detectable clinical findings, in part because this documentation may be the only formal recognition that the victim may ever 
have. As in all cases, the physician notes that the patient sought medical care and records what the victim reported about the assault. Although MSF was not a government actor and could not formally sanction the crime, the issuance of a medical certificate was still thought to be an important and symbolic act of recognition for victims.

MSF's decision to issue medical certificates as a means of formally recognizing the experience of patientvictims irrespective of whether or not victims are able to pursue prosecution in court mirrors the stated reasons that doctors who pioneered the development of medical forensic exams for documenting injuries and psychological trauma among survivors of torture gave when the Istanbul Protocol was published, namely that the act of medical documentation is a form of bearing witness to the grave abuses that survivors have endured. ${ }^{61}$ Early nurse reformers in the U.S. criminal justice context in the 1970s and 1980s who advocated for routine implementation of sexual assault medical forensic exams in hospital emergency departments stated similar intentions in their published writings: to symbolically sanction crime and communicate to victims that their experiences were being taken seriously and everything possible would be done to facilitate prosecution and hold perpetrators accountable, regardless of whether or not cases ultimately go to court. ${ }^{62}$

Standards of evidence collection may vary widely such that the medical certificate may or may not represent the findings of a standardized sexual assault medical forensic exam. In order to standardize and professionalize medical examination and associated medical evidence collection techniques for use in national jurisdictions, some initiatives have attempted to introduce, adapt, or strengthen existing implementation of domestic and international guidelines that instruct physicians and other qualified health professionals such as nurses in how to conduct a formal sexual assault medical forensic exam. In the next section, I discuss medical forensic exams conducted with surviving, adult patients.

\section{Offering Sexual Assault Medical Forensic Exams During and Immediately Following Episodes of Mass Violence for Use in Domestic Courts}

The sexual assault medical forensic exam is a standardized set of procedures and evidence collection techniques that is conducted by physicians and, in some jurisdictions, nurses or other qualified healthcare personnel. Like other medical procedures, sexual assault medical forensic exams are conducted according to guidelines and protocols, in this case ones that lay out evidence collection routines and classify the physical injuries associated with the incident. Where available, the forensic evidence collection kit (often referred to as the "rape kit") is one component of the exam that includes collection of physical and biological specimens, such as semen, saliva, blood, hair, debris, and other possible sources of trace DNA that is sent to forensic laboratories for analysis. Forensic specimens may be used to establish recent sexual contact, identify the suspect (if unknown), and link the victim to the accused or link the victim/accused to the crime scene. ${ }^{63}$ If the suspect is unknown, the possibility of forensic identification of the assailant is quite limited unless the suspect is in custody. ${ }^{64}$

Practitioners complete a form or medical certificate on which they record the victim narrative, document patient and suspect characteristics, and summarize their observations. If possible, they record and photograph physical injuries when visible. Ideally, the exam also includes specialized medical treatment such as prophylactic treatment of bacterial sexually transmitted infections, Post-exposure Prophylaxis (PeP) to prevent HIV infection in high burden settings, provision of emergency contraception if possible, and referrals to psychosocial support, counseling, and legal advocacy for patient-victims.

The WHO 2003 Guidelines for Medico-Legal Care for Victims of Sexual Violence described above codify sexual assault medical forensic exams as they were first developed within domestic criminal justice contexts in Western Europe and North America and later adapted for use outside of these contexts in middle- and lowincome country contexts.$^{65}$ For this reason, many national governments, including those in conflict and postconflict settings, have adopted these guidelines as best practice in their national jurisdictions and healthcare systems, but the degree of implementation and the capacity to collect and analyze forensic evidence varies widely.

Based on WHO guidelines and peer guidance ${ }^{66}$ published by physicians in medical journals, it appears that initial efforts to address rape in humanitarian emergencies attempted to adapt best practices developed in industrialized countries in North America and Western Europe for use in humanitarian emergency settings, particularly in refugee camps. Their references to models originally developed for use in domestic courts in industrialized countries suggests the influence of earlier advocacy to develop standardized sexual assault medical forensic exams on these later initiatives attempting to combine specialized medical care and evidence collection in humanitarian emergencies and post-conflict settings. 
For example, the $2004 \mathrm{WHO}$ guidelines developed for use in humanitarian emergencies recommends collection of forensic evidence as among the "essential components" of medical care after a rape, as long as capacity to conduct forensic analysis exists ${ }^{67}$ These 2004 WHO guidelines were published in the same year that the United Nations High Commissioner for Refugees (UNHCR) published Sexual and Gender-Based Violence Against Refugees, Returnees and Internally Displaced Persons: Guidelines for Prevention and Response as an update to their prior set of guidelines on this issue, first published in $1995{ }^{68}$ These UNHCR and WHO guidelines emerged from the same international meeting hosted by the UNHCR in 2001.

As the discussion above suggests, the availability of forensic evidence collection and analysis varies dramatically across contexts. Even where forensic laboratories are ostensibly available, capacity and willingness to conduct forensic analysis of rape kits may or may not be. At present, the use of DNA evidence in many jurisdictions is simply not available. However, even in jurisdictions in which forensic laboratory capacity is quite limited, law enforcement agencies may treat the availability of forensic evidence as necessary in order to proceed with a case. For example, a legal advocate in Burundi working with MSF reported that law enforcement authorities are very reluctant to take sexual violence cases in the absence of forensic evidence. ${ }^{69}$ Although resource-poor settings often do not have adequate facilities or infrastructure to properly collect and store physical evidence (such as semen, blood, saliva, or other sources of trace DNA such as a victim's clothing), or to conduct DNA analysis, some projects, such as the American Bar Association's Rule of Law Initiative in the Democratic Republic of Congo (DRC), have attempted to introduce rape kits.

Given the limited infrastructure available and the likely delay between incidents and subsequent medical evaluation during or after armed conflict, some organizations such as Physicians for Human Rights (PHR) have adapted the Istanbul Protocol for use in these contexts. ${ }^{70}$ As noted above, these guidelines are designed to assist physicians in conducting medical forensic exams to document evidence of physical injury and psychological sequelae among survivors of torture. PHR developed a new medical certificate for use in the Eastern Region of DRC in collaboration with Dr. Denis Mukwege, the founder of Panzi Hospital in Bukavu, and local police officers and judges. The certificate is based, in part, on an adapted version of the Istanbul Protocol and was included as a model form in the UK protocol (Annex 10). Notably, it does not include testing biological specimens for DNA in areas in which forensic analysis is not commonly available, such as the Eastern Region of DRC.

\section{Discussion and Suggestions for Future Research}

These developments raise a number of important questions: How do evidence collection techniques both reflect and come to define not only what counts as sexual violence in conflict, but also what types of claims are considered credible in the context of war crimes and mass atrocities? What are the dynamics of taking technologies developed to investigate individual claims in a domestic context (such as the medical forensic exam) and using them to prosecute cases of mass atrocities? When physical evidence is not available, does medical documentation itself become a de facto substitute for formal legal sanctioning through the courts? Can victim and witness testimony facilitate prosecution in its absence?

As described above, medical evidence collection techniques were originally developed to establish individual harms to individual victims by direct perpetrators. In environments of mass atrocities and humanitarian emergencies, these techniques are often being used to corroborate individual allegations of crime that, when considered within the broader political context in which they are occurring, are very often being committed on a far greater scale than that for which the techniques were originally designed. Even when cases involve direct perpetrators (acting alone or together), future case adjudication itself depends on a functioning legal system, which may or may not exist. Additionally, State or State-linked actors - those in a position to facilitate or impede criminal investigation and prosecution - may themselves be among those accused of committing, aiding, ordering, or failing to prevent the violations of international humanitarian law in question. Such environments recall long-standing challenges of prosecuting State officials and other high level persons responsible for torture and State-led violence in the jurisdictions in which the crimes occurred. In these circumstances, using available evidence to facilitate criminal investigation of direct or remote perpetrators with command or superior responsibility may prove difficult or impossible, and very real concerns about security - in addition to social stigma - may impede victim disclosure.

Given the scale of violence often in question and persistent barriers to prosecution, an important question is what effects medical evidence and its associated medical evidence collection techniques may have outside of courts, particularly during the patient-provider encounter in which they are implemented. Based on the 
examples described, I suggest two possible effects of these techniques within and outside of courts that merit future research: (1) their potential influence on what comes to count as sexual violence and which crimes are deemed justiciable and (2) their potential influence on formally recorded histories of mass atrocities, both within and outside of courts. I discuss each of these in turn.

\section{Potential Effects on What Comes to Count as Sexual Violence and Which Crimes are Deemed Justiciable}

Evidence collection processes to document human rights violations involve systems of classification ${ }^{71}$ and their attendant processes of standardization, ${ }^{72}$ quantification, ${ }^{73}$ and commensuration, ${ }^{74}$ which simultaneously reflect and create categories of physical injury, trauma, and violence. These categories and methods of classification in turn help to define what they purport to measure - a process of reactivity ${ }^{75}$ that science studies scholars have documented in a number of areas of empirical inquiry. Hacking demonstrates how the availability of categories to describe actions or events in fact can alter the meanings ascribed to those actions or events ${ }^{76}$ suggesting the necessity of attending to what Hacking has called the "historical ontology" of particular concepts and the associated things and types of people that they seek to represent. ${ }^{77}$

In the present case, medical evidence collection techniques may shape the category of sexual and genderbased violence in conflict itself: which crimes count, what is construed as culpability, who is considered a perpetrator. In this way, evidence collection techniques and the records they produce meet Griswold's definition of a cultural object as "shared significance embodied in form." ${ }^{\text {" }}$ In essence, evidence collection techniques not only put descriptions of physical injury and trauma into a particular form, they also produce a particular narrative of events that the technology both mediates and codifies. Further, the meaning or significance associated with the cultural object under study is likely to vary across time, space, and actors involved, particularly as the techniques and routines travel globally.

Typically doctors are not able to legally establish whether or not the crime of rape (as it is defined in available penal codes) occurred based on the findings of the exam. Indeed, they are often encouraged to limit their comments to whether or not the medical findings (if any) are consistent with the victim's account. However, they may testify to the fact that a victim sought treatment, what the victim told the doctor about the alleged assault, whether the medical findings are consistent with the victim's narrative, and what medical interventions were required, if any. The narrative recorded by the doctor is considered a formal victim statement in many jurisdictions; if it differs from statements given to the police, then it may be used to cross-examine the victim or undermine the victim's credibility in court. Further, if the doctor is the first to record the victim's narrative, then it can be treated as the most contemporaneous statement made by the victim about the crime and would carry more weight, raising the stakes of ensuring accurate and skilled recordings by medical professionals.

The presence or absence of evidence is often tied to the perceived presence or absence of the crime itself. The extent to which physical evidence of sexual violence is visible to, and therefore detectable by, a physician during an exam varies greatly, depending on a number of factors: the victim's ability to seek medical care after the assault, the availability of specialized documentation techniques, the nature and circumstances of the crime itself, and the presence of any other injuries resulting from other aspects of the crime (such as beating or maiming), and, in some cases, pregnancy. If a medical exam is conducted months or years after the incident, physical evidence of injury may not be detectable. This is also often true even when a victim is able to seek medical care within the recommended window period of 24-48 hours.

In the spaces where medicine and law overlap, legal definitions of crime and evidentiary standards of courts influence the character, use, and effects of medical evidence collection techniques designed to meet their requirements. Medical certificates may require a brief, formulaic rendering of facts to meet demands for standardized recounting of medical findings for use in court. ${ }^{79}$ In an adversarial context, available evidence of harms may be used to undermine victim testimony. ${ }^{80}$ Additionally, the application of techniques originally designed for individual case prosecution in a new context of collective crimes and mass atrocities may reinforce problematic assumptions that prosecution must continue to turn on proving individual lack of consent. By contrast, as UN High Commissioner for Human Rights Navanethem Pillay has argued, the environment of coercion and mass violence should render the question of individual consent irrelevant, if not absurd. ${ }^{81}$ In this way, legal definitions and their associated evidentiary requirements may shore up particular understandings of social problems, such as what constitutes sexual violence in conflict, and obscure others.

Yet a persistent reason for the emphasis on medical documentation and issuance of medical certificates for victims is the symbolic meaning that such a document is intended to communicate to patient-victims. As MSF's experience suggests, it is common that victims do not have visible marks or injuries on the body, 
even when mass rape is widely evident and known to all. Without visible, physical evidence, the exam cannot be said to produce clinical findings. However, although the doctor may not able to say whether or not rape occurred, he or she can issue a formal document verifying that the patient-victim sought medical care and that he or she reported the assault to a medical professional. This may be among the only acts of formal recognition that a victim may experience.

\section{Possible Effects on Formally Recorded Histories of Mass Atrocities}

A central concern is whether or not the availability of medical evidence of sexual violence in conflictaffected countries may influence the construction of formally recorded histories of mass atrocities, both within and outside of courts, and ultimately how these atrocities come to be remembered. In suggesting these effects, in this paper I briefly highlight the specific links between evidence and prosecution, thereby focusing on formally recorded histories constructed through courts. However, medical documents produced as part of routine medical care, as well as those produced explicitly in anticipation of future court proceedings, could provide a formal record of events, even if a case is never heard before a court.

As the new UK protocol notes, although physical evidence may seem like the best form of evidence, this is not necessarily the case. Documentary evidence and victim and witness testimony must often provide the link between the direct perpetrator and the individual victim, and further link the direct perpetrator to remote perpetrators with command or superior responsibility. A potential liability of the diffusion of these techniques, even in settings in which their institutionalization is shallow or relatively weak, appears to be that the availability of medical evidence collection techniques may in fact reinforce the expectation that physical evidence is - or should be - available if the claim is credible, that it is the "best" type of evidence, or that it is necessary in order to facilitate prosecution under domestic criminal law or international humanitarian law. However, medical professionals in this field have long documented that absence of clinical findings can be consistent with the victim's narrative, for example, if injury is unlikely to have occurred due to coercion or threat of force (rather than use of force), or if there is a delay between the assault and the medical exam. Nevertheless, absence of evidence may be misinterpreted as evidence that the crime did not occur, having a potential discrediting effect on the victim's narrative of events and impeding subsequent criminal investigation and prosecution.

If cases are prosecuted as international crimes in national jurisdictions, then existing domestic penal codes relating to rape and their associated legal and evidentiary requirements often must be met. If the elements of crimes, more flexible evidentiary standards, and procedural protections developed in international courts have not been adopted within national jurisdictions, then providing evidence of lack of consent and meeting both formal and informal requirements of corroboration will likely impede case adjudication and conviction. Indeed, in some national jurisdictions, cases cannot be submitted to the prosecutor's office without a medical certificate, underscoring the importance of medical documentation, the absence of which may serve as a potential barrier to investigation and prosecution, especially in conflict or post-conflict settings with weak or non-existent healthcare systems.

In this way, medical documents and their associated evidence collection techniques - through both their presence and their absence - may influence legal processes of case selection, which in turn may structure the rendering of the historical record that emerges from courts. In suggesting the possibility of these effects, I bring together scholarship on measurement and classification, ${ }^{82}$ in science and technology studies with scholarship on the materiality of cultural objects ${ }^{83}$ and the cultural and political work that objects do ${ }^{84}$ through studies of the relationship between law, courts, and collective memory formation. ${ }^{85}$ While proponents of criminal trials and Truth Commissions point to their potential to create a historical record of atrocities, hold perpetrators accountable, and promote respect for human rights, ${ }^{86}$ advocates of these approaches also recognize that legal procedures and evidentiary requirements of criminal trials may impede a full accounting of events. ${ }^{87}$

Given the possible effects suggested, future research should consider not only the impacts of these techniques according to their intended outcomes of affirming victims and increasing investigation and prosecution, but also how these techniques have been adapted for use in new environments and what their effects have been, both within and beyond courts. Given that national jurisdictions are positioned to take the lead in adjudicating violations of international humanitarian law since the establishment of the ICC, a key question is whether or not national jurisdictions will follow conventional evidentiary standards associated with domestic criminal law when prosecuting sexual violence as an international crime in local courts. The extent to which local jurisdictions develop innovative legal strategies similar to the international courts or 
adopt procedural protections for victims of sexual violence will likely shape the current and future role of medical evidence in documenting and facilitating prosecution of international crimes of sexual violence.

\section{Endnotes}

1 United Kingdom Foreign and Commonwealth Office. International Protocol on the Documentation and Investigation of Sexual Violence in Conflict: Basic Standards of Best Practice on the Documentation of Sexual Violence as a Crime Under International Law, First Edition: June 2014. https://www.gov.uk/government/uploads/system/uploads/attachment_data/file/319054/PSVI_ protocol_web.pdf.

2 For additional information on the UK's initiative to Prevent Sexual Violence in Conflict, please see the project website: http://preventsexualviolenceinconflict.tumblr.com, accessed October 7, 2014.

3 Prosecutor v. Jean-Paul Akayesu, Case No. ICTR-96-4-T, International Criminal Tribunal for Rwanda (ICTR Judgment 1998).

4 According to the founding Rome Statute of the ICC, violations of international humanitarian law under the jurisdiction of the ICC include war crimes, crimes against humanity, genocide, and the crime of aggression. Article 7 of the Rome Statute of the ICC explicitly names several forms of sexual and gender-based violence as crimes against humanity. In this paper, I focus on rape and other forms of sexual violence.

5 I use the term mass atrocities to refer broadly to violations of international humanitarian law in the context of armed conflict and mass violence against civilians.

6 In this paper, I use the term "sexual violence" to reflect the generally accepted nomenclature in the field of study. However, I wish to note that the term "sexualized violence" that some victim advocates have adopted in order to acknowledge many types of violence that are not limited to rape of women by men better reflects my approach to the subject. Legal definitions of rape and sexual assault vary by country and often also by jurisdiction. Legal definitions may or may not reflect social, political, or medical definitions. Available definitions may be limited to a very narrow understanding of "rape" as it was historically criminalized under domestic penal codes. The World Health Organization's 2002 "World Report on Violence and Health" offers an expansive definition of sexual violence but focuses on women victims (see Chapter 6). In the context of armed conflict and mass violence against civilians, sexualized violence may involve rape with objects or intentional injury to the genitalia and reproductive organs that is so severe as to amount to a form of maiming or intentional disfigurement, such as irreparable fistula or forcible penile amputation. Article 7 of the Rome Statute also recognizes sexual slavery, enforced prostitution, forced pregnancy, and enforced sterilization as forms of sexual and gender-based violence. As this brief overview suggests, a comprehensive discussion of what has come to be understood as sexual and gender-based violence (and what has not), as well as how amenable each type may be to medical documentation, is beyond the scope of this paper. Although I do not attempt to resolve the question of what counts, I hope to signal this heterogeneity and my attention to victims of all genders.

7 Carol A. Heimer, "Resilience in the Middle: Contributions of Regulated Organizations to Regulatory Success", Annals of the American Academy of Political and Social Science, 649:1 (2013): 139-156.

8 John Hagan, Justice in the Balkans: Prosecuting War Crimes in the Hague Tribunal (Chicago: University of Chicago Press, 2003).

9 John Hagan and Wenona Rymond-Richmond, Darfur and the Crime of Genocide (Cambridge: Cambridge University Press, 2009).

10 In this paper, I focus on techniques to document sexual violence among surviving patients; however, similar techniques can be used in the context of death investigation and recorded in autopsy reports.

11 The adjective "forensic" is often used almost interchangeably with the adjective "legal" (but sometimes implicitly) in order to refer to something with a legal purpose or that is intended for use in court. For example, the World Health Organization's 2003 Guidelines for Medico-Legal Care of Victims of Sexual Violence distinguishes medical examination (for the purposes of clinical treatment) and forensic evidence collection. The document defines "forensic evidence" with respect to its purpose (p. 57): "The objective of forensic evidence is to prove or exclude a physical connection between individuals and objects or places. Such evidence comprises a wide variety of substances or objects, the analysis of which requires specific, often specialized scientific skills." Forensic specimens may include semen, saliva, blood, clothing (for adherent foreign materials such as semen, blood, hair, fibers), hair, foreign material (e.g. vegetation, matted hair or foreign hairs), urine, or other sources of trace DNA. Likewise, the guidelines define the "forensic examination" with respect to its intended use in court (p. 56): "A forensic examination is formally defined as a 'medical examination conducted in the knowledge of the possibility of judicial proceedings in the future requiring medical opinion'. Although the principal aim of a forensic examination is to serve the needs of the judicial system, there can never be a justification for compromising medical care or treatment of a patient to allow a forensic procedure to be performed." As this paper will suggest, medical documentation of physical injuries and other possible clinical indicia of sexual violence during the course of a medical examination suggests the overlap of medical (treatment) and forensic (evidence collection) components in practice.

12 The medical forensic exam is a collection of procedures and technologies that are packaged together and described in associated medical guidelines and protocols. I refer to this constellation of techniques in the singular as a humanitarian technology, although I will explore the collection and use of its component parts and antecedents, such as the individual patient record and the rape kit, in addition to the medical forensic exam itself. 
13 As I discuss in greater depth elsewhere, a particular tension in the field is that medical evidence collection techniques to corroborate rape appear to have been initially developed to collect evidence that would meet historically specific definitions of "rape" as penile-vaginal penetration of a woman by a man (other than her husband) through the use of force and with evidence of victim resistance. Over time practitioners have attempted to broaden the use of techniques to capture evidence of other forms of sexual violence, and cases which involve both the use and threat of force.

14 This article draws on research conducted by the author as part of a study of the historical development and standardization of the "rape kit" and the sexual assault medical forensic exam since the 1970s (Northwestern University Institutional Review Board number STU00045675) and the history and use of medical evidence to document political and sexual violence (Northwestern University Institutional Review Board number STU00094517). Part of the research involves interviews of experts and other public figures who have gone on the record with their opinions and observations in the past and have agreed to be quoted by name.

15 Jaimie Morse, "When the Process Can’t Punish: How Sexual Assault Medical Forensic Exams ("Rape Kits") Became Routine in Hospitals" (paper presented at the annual meeting of the American Sociological Association, Denver, Colorado, August 17-20, 2012).

16 United Nations (UN) Office of the United Nations High Commissioner for Human Rights (OHCHR), Professional Training Series No. 8/Rev. 1. Istanbul Protocol: Manual on the Effective Investigation and Documentation of Torture and other Cruel, Inhuman or Degrading Treatment or Punishment, 2004 [1999]. http://www.ohchr.org/documents/publications/ training8revlen.pdf.

17 World Health Organization (WHO), Guidelines for Medico-Legal Care for Victims of Sexual Violence, 2003. http://whqlibdoc. who.int/publications/2004/924154628x.pdf.

18 WHO, Clinical Management of Rape Survivors: Developing Protocols for Use with Refugees and Internally Displaced Persons, Revised Edition, 2004. http://whqlibdoc.who.int/publications/2004/924159263X.pdf.

19 Hagan, Justice in the Balkans.

20 International Criminal Tribunal for the former Yugoslavia (ICTY), Rules of Procedure and Evidence (Rule 96), Revision 49. Originally adopted on 11 February 1994; as amended 22 May 2013. http://www.icty.org/sid/136.

21 Rome Statute of the International Criminal Court (ICC). Adopted July 17, 1998. http://www.icc-cpi.int.

22 For a more detailed overview and summary of elements of crime, modes of liability, and evidentiary issues at the ICTR, please see Annex C of the ICTR's January 2014 publication entitled, Prosecution of Sexual Violence: Best Practices Manual for the Investigation and Prosecution of Sexual Violence Crimes in Post-Conflict Regions: Lessons Learned from the Office of the Prosecutor for the International Criminal Tribunal for Rwanda. Available at http://www.unictr.org/.

23 Kelly Askin, "A Decade of the Development of Gender Crimes in International Courts and Tribunals: 1993 to 2003." Human Rights Brief 11:3 (2004): 16-19.

24 Akayesu, Judgment (paragraph 598).

25 Akayesu, Judgment (paragraphs 688, 697 (Count 14)).

26 Prosecutor v. Antono Furundžija, Case No. IT-95-17/1-T, International Criminal Tribunal for the former Yugoslavia (Judgment 1998, paragraph 185).

27 ICC Elements of Crimes, ISBN No. 92-9227-232-2. Available at http://www.icc-cpi.int.

28 Rome Statute of the ICC.

29 Article 7 of the Rome Statute of the ICC explicitly names several forms of sexual and gender-based violence as crimes against humanity: "rape, sexual slavery, enforced prostitution, forced pregnancy, enforced sterilization, or any other form of sexual violence of comparable gravity" and gender-based persecution "when committed as part of a widespread or systematic attack directed against any civilian population."

30 ICTR Rules of Procedure and Evidence (Rule 96), Revision 22. Originally adopted on 29 June 1995; as amended 10 April 2013. Available at http://www.unictr.org/.

31 ICTY Rules of Procedure and Evidence, Rule 96.

32 Specifically, under Rule 96 of the ICTY and ICTR RPEs, the prosecution must show that the victim either "(a) has been subjected to or threatened with or has had reason to fear violence, duress, detention or psychological oppression, or (b) reasonably believed that if the victim did not submit, another might be so subjected, threatened or put in fear." In very limited circumstances, the defense may submit evidence of consent, but only after The Trial Chamber has had the opportunity to determine the relevance and credibility of the evidence during an in camera session (closed to the public) and has granted approval to admit it.

33 ICC Rules of Procedure and Evidence (Rules 70, 71, 72), ISBN No. 92-9227-278-0. http://www.icc-cpi.int.

34 The landmark rape cases at the ICTY according to the ICTY Office of Outreach include Furundžija (IT-95-17/1) "Lašva Valley", Krstić (IT-98-33) "Srebrenica-Drina Corps"; Kunarac et al. (IT-96-23 \& 23/1) "Foča”; Mucić et al. (IT-96-21) "Čelebići Camp"; and Tadić (IT-94-1) "Prijedor". The landmark ICTY rape cases involved sexual violence in the context of detention and victim and witness testimony served as the principal evidence for the prosecution's case. See the ICTY Office of Outreach webpage, "Crimes of Sexual Violence, Landmark Cases," accessed at http://www.icty.org/sid/10314 (last accessed October 7, 2014).

35 Furundžija, Judgment. 
36 Prosecutor v. Radislav Krstić, Case No. IT-98-33-T, International Criminal Tribunal for the former Yugoslavia (Judgment 2001).

37 Prosecutor v. Dragoljub Kunarac, Radomir Kovac and Zoran Vukovic, Case No. IT-96-23-T\& IT-96-23/1-T, International Criminal Tribunal for the former Yugoslavia (Judgment 2001).

38 Prosecutor v. Zejnil Delalic, Zdravako Mucić also known as "Pavo", Hazim Delic, and Esad Landzo also known as "Zenga", Case No. IT-96-21-T, International Criminal Tribunal for the former Yugoslavia (Judgment 1998).

39 Prosecutor v. Dusko Tadić, Case No. IT-94-1-T, International Criminal Tribunal for the former Yugoslavia (Judgment 1997).

40 ICTR, Prosecution of Sexual Violence: Best Practices Manual for the Investigation and Prosecution of Sexual Violence Crimes in Post-Conflict Regions: Lessons Learned from the Office of the Prosecutor for the International Criminal Tribunal for Rwanda, 2014. http://www.unictr.org/portals/0/English/Legal/Prosecutor/ProsecutionofSexualViolence.pdf. This publication names two cases in particular as landmark decisions: Akayesu and Gacumbitsi. Several other rape cases are also described.

41 Akayesu, Judgment.

42 Prosecutor v. Sylvestre Gacumbitsi, Case No. ICTR-2001-64-T, International Criminal Tribunal for Rwanda (Judgment 2004).

43 Anne-Marie de Brouwer, "Gacumbitsi Judgement," in Annotated Leading Cases of International Criminal Tribunals: The International Criminal Tribunal for Rwanda 2005-2006, ed. Göran Sluiter and André Klip (Antwerp-Oxford-Portland: Intersentia, 2009), 583-594.

44 Naventhem Pillay, "Address-Interdisciplinary Colloquium on Sexual Violence as International Crime: Sexual Violence: Standing by the Victim," Law \& Social Inquiry 35: 4 (2010): 847-853.

45 Patricia Viseur Sellers, "The Prosecution of Sexual Violence in Conflict: The Importance of Human Rights as Means of Interpretation.” UN OHCHR working paper, undated. http://www.ohchr.org/Documents/Issues/Women/WRGS/Paper Prosecution of Sexual Violence.pdf.

46 UN Human Rights Commission, Situation of Human Rights in the Territory of the former Yugoslavia: Report on the Situation of Human Rights in the Territory of the Former Yugoslavia submitted by Mr. Tadeusz Mazowiecki, Special Rapporteur of the Commission on Human Rights, pursuant to Commission resolution 1992/S-1/1 of 14 August 1992, UN Document E/ CN.4/1993/50.

47 Shana Swiss and Joan E. Giller, "Rape as a Crime of War: A Medical Perspective," JAMA: Journal of the American Medical Association, 270:5 (1993): 612-15.

48 Lynn L. Amowitz, Glen Kim, Chen Reis, Jana L. Asher, and Vincent Iacopino, "Human Rights Abuses and Concerns about Women's Health and Human Rights in Southern Iraq," JAMA: Journal of the American Medical Association, $291: 12$ (2004): $1471-79$

49 Lynn L. Amowitz, Chen Reis, Kristina Hare Lyons, Beth Vann, Binta Mansaray, Adyinka M. Akinsulure-Smith, Louise Taylor, and Vincent Iacopino, "Prevalence of War-related Sexual Violence and Other Human Rights Abuses among Internally Displaced Persons in Sierra Leone," JAMA: Journal of the American Medical Association, $287: 4$ (2002): 513-21.

50 Kirsten Johnson, Jana Asher, Stephanie Rosborough, Amisha Raja, Rajesh Panjabi, Charles Beadling, and Lynn Lawry, "Association of Combatant Status and Sexual Violence with Health and Mental Health Outcomes in Postconflict Liberia," JAMA: Journal of the American Medical Association, 300:6 (2008): 676-90.

51 Kirsten Johnson, Jennifer Scott, Bigy Rughita, Michael Kisielewski, Jana Asher, Ricardo Ong, and Lynn Lawry, "Association of Sexual Violence and Human Rights Violations with Physical and Mental Health in Territories of the Eastern Democratic Republic of the Congo," JAMA: Journal of the American Medical Association, 304:5 (2010): 553-62.

52 Furundžija, Judgment.

53 Prosecutor v. Charles Ghankay Taylor, Case No. SCSL-03-01-T, Special Court for Sierra Leone (Judgment 2012).

54 Taylor, Judgment (p. 434-435).

55 WHO, Clinical Management of Rape Survivors, p. 14.

56 WHO, Clinical Management of Rape Survivors.

57 Amnesty International, "Combatting Sexual Violence in Conflict: Recommendations to States at the Global Summit to End Sexual Violence in Conflict (10-13 June 2014)" (working paper, May 2014). http://www.amnesty.org/en/library/asset/ IOR53/006/2014/en/621bb5a4-b0b0-41c6-98cc-33ffdce90c3b/ior530062014en.pdf.

58 Françoise Bouchet-Saulnier and Fabien Dubuet. "Legal or Humanitarian Testimony? History of MSF’s Interactions with Investigations and Judicial Proceedings." Fondation Médecins Sans Frontières, the Centre de Réflexion sur l'Action et les Savoirs Humanitaires (CRASH), Les Cahiers du CRASH, Paris, France, April 2007. http://www.msf-crash.org/drive/0633cahier-justice-va.pdf.

59 Médecins Sans Frontières (MSF), "Shattered Lives: Immediate Medical Care Vital for Sexual Violence Victims," March 2009. http://www.doctorswithoutborders.org/sites/usa/files/MSF Shattered-Lives Sexual-Violence.pdf.

60 Rony Brauman, MD, interview by Jaimie Morse, June 3, 2014.

61 Vincent Iacopino, Onder Ozkalipci, and Caroline Schlar, "The Istanbul Protocol: International Standards for the Effective Investigation and Documentation of Torture and Ill Treatment," The Lancet, 354:9184 (1999): 1117. 
62 Morse, "When the Process Can't Punish."

63 See footnote \#11 above that defines forensic evidence.

64 Separate guidelines also exist to direct healthcare practitioners in collecting evidence from suspects in custody.

65 WHO, Guidelines for Medico-Legal Care for Victims of Sexual Violence.

66 For example, writing on behalf of MSF Canada in 2000, two physicians published a guiding set of best practices in the Canadian Medical Association Journal (CMAJ) for doctors who may work in humanitarian and emergency settings. The list of specialized medical care and treatment includes the collection of simple forensic evidence, such as taking a swab to look for traces of sperm that may be detected under a microscope as proof of sexual contact when forensic identification techniques such as DNA testing are not available. In this case, the anticipated setting in which the medical forensic exam would be implemented was a refugee camp, reflecting increasing concerns about violence against women in the 1990s and reports by media and human rights organizations about high rates of sexual violence in refugee camps, particularly while women were collecting water and firewood for their families at a distance from the camp.

67 WHO, Clinical Management of Rape Survivors.

68 United Nations High Commission on Refugees, Sexual and Gender-Based Violence Against Refugees, Returnees and Internally Displaced Persons: Guidelines for Prevention and Response, 2004. http://www.unhcr.org/3f696bcc4.html.

69 MSF, Shattered Lives.

70 PHR's efforts to introduce, professionalize, and institutionalize medical forensic exams are occurring in countries that have been referred to the ICC for investigation of violations of international humanitarian law. For more information on PHR's Sexual Violence in Conflict Program, see http://physiciansforhumanrights.org/issues/rape-in-war/program-on-sexualviolence-in-conflict-zones.html, accessed October 7, 2014.

71 Geoffrey C. Bowker and Susan Leigh Star, Sorting Things Out: Classification and Its Consequences (Cambridge: MIT Press, 2000).

72 Stefan Timmermans and Steven Epstein, "A World of Standards But Not a Standard World: Toward a Sociology of Standards and Standardization," Annual Review of Sociology, 36 (2010): 69-89.

73 Wendy Nelson Espeland and Mitchell L. Stevens, “A Sociology of Quantification,” European Journal of Sociology, 49:3 (2008): 401-436.

74 Wendy Nelson Espeland and Mitchell L. Stevens, “Commensuration As a Social Process," Annual Review of Sociology, 24 (1998): 313-343.

75 Wendy Nelson Espeland and Michael Sauder, "Rankings and Reactivity: How Public Measures Recreate Social Worlds," The American Journal of Sociology, 113:1 (2007): 1-40.

76 Ian Hacking, Rewriting the Soul: Multiple Personality and the Sciences of Memory (Princeton: Princeton University Press, 1995).

77 Ian Hacking, Historical Ontology (Cambridge: Harvard University Press, 2004).

78 Wendy Griswold, Renaissance Revivals: City Comedy and Revenge Tragedy in London Theatre from 1576 to 1980 (Chicago: University of Chicago Press, 1986), 5.

79 Didier Fassin and Estelle d'Halluin, “The Truth from the Body: Medical Certificates as Ultimate Evidence for Asylum Seekers," American Anthropologist, 107:4 (2008): 597-608.

80 Kirsten Campbell, "Legal Memories: Sexual Assault, Memory, and International Humanitarian Law," Signs: Journal of Women in Culture and Society, 28:1 (2002): 149-176.

81 Pillay. "Address-Interdisciplinary Colloquium on Sexual Violence as International Crime."

82 Steven Epstein, Inclusion: The Politics of Difference in Medical Research (Chicago: University of Chicago Press, 2007); Steven Epstein, "Culture and Science/Technology: Rethinking Knowledge, Power, Materiality, and Nature," The Annals of the American Academy of Political and Social Science, 619:1 (2008): 165-182.

83 Terence E. McDonnell, "Cultural Objects as Objects: Materiality, Urban Space, and the Interpretation of AIDS Media in Accra, Ghana, The American Journal of Sociology, 115:6 (2010): 1800-1852.

84 Ken Alder, The Lie Detectors: The History of an American Obsession (Lincoln: University of Nebraska Press, 2007).

85 Joachim J. Savelsberg and Ryan D. King, "Law and Collective Memory," Annual Review of Law and Social Science, 3 (2007): 189-211.

86 Ellen Lutz and Kathryn Sikkink, "The Justice Cascade: The Evolution and Impact of Foreign Human Rights Trials in Latin America," Chicago Journal of International Law, 2:1 (2001): 1-33.

87 Mark Osiel, Mass Atrocity, Collective Memory, and the Law (New Brunswick, NJ: Transaction Publishers, 2000) 